\title{
KÖZÖSSÉGI ENERGIA, MINT AZ ENERGIAÁTMENET EGY LEHETSÉGES ESZKÖZE
}

\author{
Takácsné Papp Adrienn \\ egyetemi tanársegéd, Miskolci Egyetem, Gazdaságtudományi Kar, Gazdálkodástani Intézet \\ 3515 Miskolc-Egyetemváros, e-mail: vgttakacs@uni-miskolc.hu

\section{Horváth Ágnes} \\ intézetigazgató, egyetemi docens, Miskolci Egyetem, Gazdaságtudományi Kar, Gazdálkodástani Intézet \\ 3515 Miskolc-Egyetemváros, e-mail: vgthagi@uni-miskolc.hu
}

\begin{abstract}
Absztrakt
Az energiaátmenet, a közösségi energia és a társadalmi innováció kérdéskörét a tudományos világ mind szélesebb érdeklödése övezi. A közösségi energiatermelés, mint a társadalmi innováció egy lehetséges formája hathatósan képes hozzájárulni az energiaátmenet megvalósulásához. Jelen cikkben a szakirodalmi források feldolgozásával kivánjuk bemutatni a közösségi energiatermelés e jelentöségteljes szerepét. A közösségi energiatermelésben Németország, Dánia és Svédország tölt be vezetö szerepet, mindazonáltal Magyarországon is egyre növekszik azon települések száma, amelyek egyre inkább függetlenednek a fosszilis energiahordozóktól.
\end{abstract}

Kulcsszavak: energiaátmenet, decentralizált energiatermelés, közösségi energia, társadalmi innováció

\section{Abstract}

There has been a growing scientific interest in the topic energy transition, community energy and social innovation. Community energy production can be interpreted as a form of social innovation, and it has the potential to significantly contribute to energy transition. This article provides a comprehensive literature review on this important role of the community energy production. The area is most developed in Germany, Denmark and Sweden, but the number of Hungarian settlements getting rid of fossil fuels is on the rise as well.

Keywords: energy transition, decentralised energy production, energy community, social innovation

\section{Bevezetés}

A növekedésorientált világ egyre fokozódó gazdasági és társadalmi feszültséget generál az emberek megélhetése, a munkanélküliség, az energiafüggőség és -szegénység területén, amely alapjaiban fenyegeti az emberek méltányos, biztonságos és egészséges élethez való jogát valamint a természeti környezet épségét. A társadalmi innováció fontossága első ízben a 2008-as világválságból való kilábalás egyik eszközeként jelent meg, majd egyre jelentősebbé vált annak gazdaságot, társadalmat formáló ereje. (Slee, 2020) Cajaiba-Santana definíciója szerint „a társadalmi innovációk olyan kollektív, szándékos és célorientált fellépések eredményeként létrejövö új társadalmi gyakorlatok, amelyek a társadalmi célok megvalósulásának módját újraértelmezve segítik elö a társadalmi változásokat" (Slee 2020, pp. 158.) Kocziszky et al. (2017) értelmezésében „A társadalmi innováció új vagy újszerü válaszokat ad egy közösség problémáira azzal a céllal, hogy növelje a közösség jólétét." (Kocziszky et 
al. 2017, pp.16.) „A közösségi energia olyan fenntartható energiatermelö vagy energia-megtakaritó beruházás, amelyet helyi lakosok egy csoportja, esetleg az önkormányzat valósít meg, saját tulajdonban és kezelésben. Így a helyi közösség dönt minden fontos kérdésben, helyben tartva a munkahelyeket és a bevételeket, s élvezve az energiatermelés összes elönyét." (Magyar 2016, pp. 1.) O’Connor (2010) szerint az energiaátmenet „a társadalom energiafogyasztási szokásaiban bekövetkező nagy volumenü változás, amely potenciálisan befolyásolja az eröforrásokat, a szállitókat, az átalakitási módokat és a szolgáltatásokat". (in Sovacool, 2016, pp. 203.) Selvakkumaran és Ahlgren (2021) a transzformatív társadalmi innováció keretrendszerén keresztül elemzi és értelmezi a helyi energiaátmenet a közösségi energia és a társadalmi innováció kapcsolatát, és megállapítják, hogy a társadalmi innovációk, beleértve a közösségi energia megoldásokat is sikeresen járulnak hozzá a helyi energiaátmenethez. (Selvakkumaran; Ahlgren, 2021)

Korábbi munkánkban (Kádárné Horváth; Takácsné Papp, 2019) csokorba szedtük a társadalmi innováció és a közösségi energiatermelés kapcsolódási pontjait. Megállapítottuk, hogy a közösségi energia azáltal, hogy erősíti a lakosság és szükebb környezetének önszervezö erejét, pozitívan hat a munkahely teremtésre és a település munkahelymegtartó képességére, növeli a megújuló energiát hasznosító technológiák jelenlétét, csökkenti az energiaelöállítási költségeket, és a környezetterhelést, a szerényebb jövedelmü lakosság számára elérhetőbbé teszi a megfizethető energiát, így igazi társadalmi innovációnak tekinthető. Jelen cikkünkben megvizsgáljuk az energiaátmenet kérdéskörét, és ezáltal tovább visszük és elmélyítjük a korábbi gondolatmenetünket. Első lépésként a ScienceDirect online szakfolyóirat-adatbázisban végeztünk kulcsszavas keresést, amelynek eredményét az 1. táblázat foglalja össze.

1. táblázat. Az energiaátmenet, a közösségi energia és a társadalmi innováció összefonódása a tudományos publikációkban

\begin{tabular}{|l|c|c|c|c|c|c|c|c|}
\hline \multicolumn{1}{|r}{ Publikálás éve } & $\mathbf{2 0 1 3}$ & $\mathbf{2 0 1 4}$ & $\mathbf{2 0 1 5}$ & $\mathbf{2 0 1 6}$ & $\mathbf{2 0 1 7}$ & $\mathbf{2 0 1 8}$ & $\mathbf{2 0 1 9}$ & $\mathbf{2 0 2 0}$ \\
\hline Keresés & & & & & & & & \\
\hline Energiaátmenet (energy transition) & 602 & 723 & 781 & 1038 & 1363 & 1729 & 1962 & 2791 \\
\hline +Közösségi energia (community energy) & 8 & 10 & 14 & 39 & 48 & 101 & 102 & 141 \\
\hline +Társadalmi innováció (social innovation) & 2 & 2 & 2 & 10 & 7 & 12 & 10 & 35 \\
\hline
\end{tabular}

Forrás: Saját szerkesztés ScienceDirect adatbázisa alapján (ScienceDirect keresés 2020.december 29én)

Az adatok 2013-2020 között a tudományos közvélemény egyre élénkülő figyelemét mutatják, így az energiaátmenet, a közösségi energia és a társadalmi innováció szoros összefonódását vizsgáló kutatások szükségességét és indokoltságát támasztják alá. Jelen publikáció szakirodalmi forrásokon és nyilvánosan elérhető adatbázisok szolgáltatta adatok elemzésén keresztül kísérli meg átfogóbban értelmezni a közössági energiatermelést, mint az energiaátmenet egy lehetséges eszközét.

\section{Az Európai Unió energiaátmenetben betöltött szerepe}

A Nemzetközi Megújuló Energia Ügynökség (IRENA) becslése szerint 2050-re a megújuló energiaforrások energiatermelésen belüli aránya a $60 \%$-ot is elérheti, zömmel a nap- és a szélenergia hasznosításával. (IRENA 2019b., pp. 28.) A 2009-ben hatályba lépő Lisszaboni szerződésben (EU 2007/C 306/0 176a cikkének 1/c pontja) már megfogalmazódik az energiahatékonyság, az energiatakarékosság, az új- és megújuló energiaforrások iránti fokozott igény, amelynek köszönhetően az energia az Európai Unión belül a nemzetállamok közötti megosztott kompetenciává vált. (Lepesant, 
2017) A jövőben várhatóan az éghajlatváltozás elleni küzdelem, így a megújuló energiák hasznosítása is „a polgárokhoz legközelebbi kormányzati szinten a helyi önkormányzatok” köré szerveződik. (Európai Bizottság 2019, pp. 106.) A legfrissebb 2018-as adatok szerint a megújuló energia részaránya az Európai Unió 27 tagállamában 18,88\%, az üvegházhatású gázkibocsátás (ÜHG) az 1990. évi érték 80,96\%-a (Eurostat h.), az energiahatékonyság pedig 8,864 PPS/kgoe volt. (Eurostat d,e,g.) A megújuló energiák legjellemzöbb hasznosulási területei közé tartozik a villamosenergia-termelés, az épületek hütése és fütése, valamint a közlekedés. Elterjedésüket az elmúlt időszakban nagyban segítette a beruházási költségeik jelentős csökkenése. 2017-ben a villamosenergia-termelés 30,8\%-a, a hütés és fütés 19,5\%-a, a közlekedés 7,6\%-a megújuló energián alapult. (Alves, et al., 2019) (Sveinbjörnsson, et al., 2017) (OECD/IEA; IRENA, 2017) A 2018-as Új Megújuló Irányelv legfontosabb eredménye az, hogy a háztartásokat, közösségeket és a vállalkozásokat felruházta az önálló energiatermelés, felhasználás és értékesítés jogával, így utat nyitott a megújuló közösségi energia kezdeményezéseknek. (EU 2018/2001) Az Európai Unió tagországainak nagy része energia behozatalra szorul, ezért is számít hatalmas előrelépésnek a megfizethető, tiszta és fenntartható energiát biztosító Energiaunió jogi kereteinek 2019-es véglegesítése. Magyarország, elsődlegesen a napelemes rendszerek segítségével, 2030-ra 20\%-os megújuló részarányt kíván elérni. (NEKT)

Az 1. táblázat az Energiaátment Index alapján hasonlítja össze az Európai Unió 27 tagállamát annak értéke, valamint a tagországok uniós és globális rangsora tekintetében.

1. táblázat: Az Energiaátmenet Indexe (2019, EU-27)

\begin{tabular}{|c|c|l|c|c|c|l|c|}
\hline $\begin{array}{c}\text { EU 27 } \\
\text { sorrend }\end{array}$ & $\begin{array}{c}\text { Globális } \\
\text { sorrend }\end{array}$ & \multicolumn{1}{|c|}{ Ország } & $\begin{array}{c}\text { Energiaátmenet } \\
\text { Index (2019) }\end{array}$ & $\begin{array}{c}\text { EU 27 } \\
\text { sorrend }\end{array}$ & $\begin{array}{c}\text { Globális } \\
\text { sorrend }\end{array}$ & Ország & $\begin{array}{c}\text { Energiaátmenet } \\
\text { Index (2019) }\end{array}$ \\
\hline 1. & 1. & Svédország & $74,9 \%$ & 15. & 24. & Szlovénia & $63,6 \%$ \\
\hline 2. & 4. & Finnország & $73,0 \%$ & 16. & 25. & Spanyolország & $63,5 \%$ \\
\hline 3. & 5. & Dánia & $72,2 \%$ & 17. & 28. & Málta & $62,0 \%$ \\
\hline 4. & 6. & Ausztria & $70,7 \%$ & 18. & 29. & Olaszország & $61,7 \%$ \\
\hline 5. & 8. & Franciaország & $68,6 \%$ & 19. & 33. & Szlovákia & $61,0 \%$ \\
\hline 6. & 9. & Hollandia & $68,5 \%$ & 20. & 40. & Románia & $59,3 \%$ \\
\hline 7. & 12. & Írország & $67,1 \%$ & $\mathbf{2 1 .}$ & $\mathbf{4 1 .}$ & Magyarország & $\mathbf{5 9 , 2} \%$ \\
\hline 8. & 15. & Luxemburg & $65,5 \%$ & 22. & 42. & Horvátország & $59,2 \%$ \\
\hline 9. & 16. & Portugália & $65,0 \%$ & 23. & 45. & Ciprus & $58,3 \%$ \\
\hline 10. & 17. & Németország & $64,9 \%$ & 24. & 49. & Csehország & $57,3 \%$ \\
\hline 11. & 19. & Litvánia & $64,5 \%$ & 25. & 54. & Görögország & $56,2 \%$ \\
\hline 12. & 20. & Észtország & $64,2 \%$ & 26. & 75. & Lengyelország & $51,4 \%$ \\
\hline 13. & 22. & Belgium & $63,9 \%$ & 27. & 77. & Bulgária & $51,0 \%$ \\
\hline 14. & 23. & Lettország & $63,7 \%$ & - & - & & - \\
\hline
\end{tabular}

Forrás: (WEF 2019a, pp. 11.) alapján saját szerkesztés

Az Energiaátmenet Indexét minden évben a World Economic Forum (WEF) számítja ki és teszi közzé. 2019-ben 115 országra vonatkozóan publikálta az energiaátmenetet meghatározó 40 gazdasági, társadalmi, müszaki paraméterekből összeállított kompozit indexét, amely magában foglal olyan indikátorokat, amelyek kiterjednek az energiaszegénység, az ellátási láncok, az intézmények, a pénzügyi rendszer, illetve a humán tőke értékelésére. A mutató az országok energiarendszerének teljesítménye 
(system performance) és az energiaátmenetre való felkészültségük (transition readiness) alapján differenciál. (WEF, 2019b.) Az 1. táblázat alapján látható, hogy Svédország, Finnország, Dánia nem csak uniós, hanem világviszonylatban is vezető szerepet tölt be az energiaátmenetben, ugyanakkor a közösségi energia tekintetében is élenjárónak tekinthetők. (Lepesant, 2017) Németország esetén meglepő a 10.; 17. helyezés, hiszen mind az energiaátmenetnek (energiafordulat-Energiewende), mind pedig a közösségi energiatermelés egyik vezető országa. (Lepesant, 2017) A rangsorbéli helyezését többek között az energiarendszerének a struktúrája (szénrégiók), illetve a magas energiaárak rontják, ugyanakkor a megújulóenergiát támogató politikája kiemelkedőnek számít. Magyarország uniós szinten sajnálatosan csak a 21. helyet, globálisan pedig a 41. helyet foglalja el. Bulgária, Lengyelország, Görögország és Ciprus az utolsó helyen szerepelnek. A mélyebb ok-okozati elemzéseket a jelen cikk terjedelme és elsődleges fókusza nem indokolja. Néhány statisztikai példa segítségével azonban megpróbáljuk árnyalni a képet.

2018-ban Svédország az előző évekhez képest tovább tudta növelni a megújuló energia használatát (54,65\%), Hollandia viszont mindösszesen csak 7,39\%-kos részaránnyal bírt. Magyarország 2018-ban 12,49\%-kal az uniós átlag alatt teljesített. (Eurostat, 2019) (Eurostat a.) A lakosság energiafogyasztása szempontjából kedvező, hogy az energiatakarékos megoldások egyre elterjedtebbek, illetve a háztartások egyre nagyobb arányban használnak megújuló energiát. A legtöbb energiát fogyasztó tagállam 2018-ban Finnország volt, a legkevesebbet Málta használta fel. A magyar háztartások kereslete 2018-ban az uniós tagországok átlagával közel azonos szintet mutott, amelyben visszatükröződnek az elmúlt évek energiatakarékosságot ösztönző programjainak jótékony hatásai is. (Eurostat, 2019) (Eurostat b.,c.) Mindennek ellenére a háztartások még mindig a költségvetésük jelentős részét fordítják lakásfenntartásra és energiára. A fütési célú fogyasztás csökkenését javarészt az államilag támogatott panelprogramok népszerüsége, valamint az energiatudatosabb lakosság magáncélú hőszigetelési kezdeményezései segíthetik. (KSH, 2019) 2018-ban az Európai Unió polgárainak 8,73 százaléka vélte úgy, hogy nem képes önerejéből és képességeihez mérten megfelelően füteni az otthonát, tehát energiaszegénységben élnek. Fellegi és Fülöp (2012, pp.1.) definíciója szerint „egy háztartás akkor tekinthetö energiaszegénynek, ha az nem képes megfelelö szintre füteni lakását, illetve bevételeinek egy meghatározott százalékánál többet költ energiaszámláira”. Az Energy Poverty Observatory a fenti definíciót tovább árnyalja azzal, hogy az energiaszegénység kategóriájába beleérti a "hütéshez, világitáshoz és a készülékek müködtetéséhez szükséges energiát" is, tehát mindazt az energiát, amely a „tisztességes életszinvonal és a polgárok egészségének biztositásához elengedhetetlen”. (EPOV) A tagállamok közül Bulgária lakossága küzd leginkább a problémával. Ezzel ellentétben 2018-ban a finn és az osztrák otthonok voltak legkevésbé kitéve a hideg időjárás viszontagságainak, a háztartások mindösszesen 0,9\%-a érezte úgy, hogy nem képesek melegen tartani az otthonaikat. 2018-ban a magyar lakosság 6,1\%-a számára jelentett nehézséget az otthonaik fütése. (Eurostat f.)

\section{A közösségi energia, mint az energiaátmenet egy lehetséges eszköze}

Európa szerte az energiafüggetlenség és a környezetvédelem szellemében egyre elterjedtebb a lakossági, vállalati és önkormányzati részvétel keretében megvalósuló közösségi energiatermelés. Az irodalomban a „helyi energiának” nincs szigorú meghatározása, általában rugalmas fogalomként kezelik, azaz különböző kontextusokban és ágazatokban másként értelmezik azt. A fogalom a tevékenységek és struktúrák széles skáláját foglalja magában, ideértve a hő vagy villamosenergiatermelő megoldásokat, de ehhez a kérdéskörhöz értendők a helyi hatóságok vagy állampolgárok keresletcsökkentő tevékenységei is. (Gancheva, 2018) Az elmúlt években az energiatervezés egyre nagyobb szerephez jut a nemzetgazdaság alsóbb szintjein is (Lepesant, 2017) (EU 2018/2001) (EU 2019/944), beleértve a 
közösségi, lakossági szintet, ahol az energiaátmenet gyorsabban képes lezajlani. (Smil, 2016) Az energiaátmenet megvalósulását alapvetően segíti a megújuló energiák elfogadása, amelynek kulcsa „,a technológiai innováció, a helyi kezdeményezések, az uniós és nemzeti szinten biztositott jogi és gazdasági feltételek". (Comodi et. al., 2012 in Lepesant, 2017, pp. 547.) Ugyanakkor Lepesant (2017) rávilágít arra is, hogy ezeknek a technológiai megoldásoknak a társadalmi elfogadottsága még nem kielégítő mértékü. Wüstenhagen, Wolsink és Bürer (2007) (in Lepesant, 2017, pp. 548.) az elfogadás három szintjét, nevezetesen szocio-politikai, közösségi- és piaci elfogadást különbözteti meg. A szociopolitikai elfogadás a legáltalánosabb szintnek tekinthető. A közösségi elfogadottság a helyi stakeholderek és hatóságok nyitottságát jelenti a megújuló projektek irányába. Simon, Wüstenhagen (2006) valamint Musall, Kuik (2011) kutatásai cáfolták a „Not In My Backyard” (NIMBY-Ne az én szomszédságomban) elméletét, miszerint a helyben élök inkább ellenzik a szélenergiát hasznosító beruházásokat, és igazolták, hogy a távolabb élő lakosság részéről sokkal inkább várható ez a fajta hozzáállás. A piaci elfogadottság az új innovációk elfogadását és terjedését jelenti. (Lepesant, 2017) A közösségi energiatermelő megoldásoknak legnagyobb hagyománya Dániában és Németországban van. Dániában a szélenergiát már az 1970-es évektől (Cossent, et al., 2009), Svédországban, Hollandiában, Franciaországban és Németországban pedig az 1990-es évektől fokozott érdeklődés övezi. (Lepesant, 2017). Dánia esetében a szélerőmüvek telepítését meghatározott (20\%-os) közösségi tulajdonhoz kötik, míg Németországban az atomerőmúvi kapacitás folyamatos csökkenése mellett a közösségi megújuló energiatermelés töretlenül emelkedik. (Bertram, Primova szerk., 2018) (Székffy, 2014) Tehát a közösségi energetikai megoldások, mint társadalmi innovációk is jelentősen képesek hozzájárulni a társadalmi, gazdasági feszültségek oldásához, az energiaszegénység leküzdéséhez. (Selvakkumaran és Ahlgren, 2021) (Kádárné Horváth, Takácsné Papp, 2019.) 2018. június 27-én az uniós jogalkotás a közösségi energiatermelés tekintetében mérföldkőhöz érkezett. Az EU 2019/944 valamint a 2018/2001 Irányelvekben megfogalmazódtak az energia közösségekre vonatkozó jogok és kötelezettségek, amelyeknek 2021-ig kell megjelenniük a hazai jogszabályokban. A jelenlegi energia rendszerek jellemzően még centralizált formában müködnek, de ezzel párhuzamosan egyre inkább elterjednek a decentralizáltság irányába mutató technológiai megoldások is, amelyek a megújuló energiaforrások hasznosításának jellemző formái. Az elosztott energia rendszer a decentralizált energiatermelés azon típusa, amelynek keretében már maguk a termelők a felhasználók, akik lehetnek magánszemélyek, kisvállalkozások és/vagy helyi közösségek. (Vezzoli et al. 2018, pp. 25.) Ez utóbbi megvalósulás mind nagyobb elterjedésének az igénye az Európai Unió Új Megújuló Energia Irányelvében is megfogalmazódik. (EU 2018/2001) Vezzoli és szerzőtársai 2018-as munkájukban kiemelték az elosztott energiatermelés környezeti és társadalmi előnyeit. Környezeti előnyként sorakoztatják fel az elosztott energiatermelés lokális jellegét, amely így a helyi megújuló erőforrásokra támaszkodva csökkenti az üvegházhatású gázok kibocsátását, a környezetre gyakorolt kedvezőtlen hatásokat, valamint az elosztási veszteségeket. Társadalmi előnyként többek között a közösség önrendelkezését és a társadalmi egyenlötlenségek csökkenését emelik ki. A decentralizált energiatermelés pozitív hozadékaként említhető az új szereplök, különösen a prosumerek, $a z$ aggregátorok és az aktív fogyasztók megjelenése. (IRENA 2019a., pp. 6) Vezzoli és szerzőtársi Skierkara (2016) hivatkozva hangsúlyozzák, hogy „,az elosztott megújuló energia rendszereknek köszönhetöen 2025-ig várhatóan 1 milliárdnál is többen juthatnak energiához”. (Vezzoli 2018, pp. 24.) Az Európai Unió számára bármennyire is kívánatos a fent említett energiatermelő modellek mind szélesebb elterjedése, mégis típustól függően számos tényező hátráltatja azok megvalósulását. A 2. táblázat az elosztott/decentralizált megújuló energia rendszerek megvalósulását korlátozó tényezőket mutatja be. A Tounquet (2019) az Európai Unió 18 tagállamára kiterjedő kérdőíves felmérése alapján (Ausztria, Csehország, Egyesült-Királyság, Dánia, Észtország, Finnország, Franciaország, Görögország, 
Horvátország, Lengyelország, Litvánia, Luxemburg, Németország, Portugália, Spanyolország, Svédország, Szlovénia) az energia közösségek fő hajtóerejét a helyi közigazgatás, a helyi hatóságok és az önkormányzatok jelentik. Az ismét önkormányzati tulajdonba vétel (remunicipalization), a decentralizáció (devolution), valamint a részvételen alapuló kormányzás (participative governance) mind hozzájárulnak a helyi energiatulajdon-modellek kialakításához. (Gancheva, 2018)

2. táblázat Az elosztott/decentralizált megújuló energiarendszerek megvalósulását akadályozó tényezök

\begin{tabular}{|c|c|c|}
\hline $\begin{array}{l}\text { VIZSGÁLAT } \\
\text { FÓKUSZA }\end{array}$ & AKADÁLYOZÓ TÉNYEZŐK & VIZSGÁLAT \\
\hline $\begin{array}{l}\text { PV (fotovoltaikus) } \\
\text { rendszerek }\end{array}$ & $\begin{array}{l}\text { Szocio-technikai } \\
\text { Menedzsment } \\
\text { Gazdasági } \\
\text { Politikai }\end{array}$ & $\begin{array}{l}\text { Karakaya, } \\
\text { Sriwannawit } \\
\quad(2015)\end{array}$ \\
\hline $\begin{array}{l}\text { Megújuló } \\
\text { technológiák } \\
\text { bevezetése }\end{array}$ & $\begin{array}{l}\text { Politikai és jogi } \\
\text { Technikai } \\
\text { Pénzügyi }\end{array}$ & $\begin{array}{c}\text { Mboumboue, } \\
\text { Njomo (2016) }\end{array}$ \\
\hline $\begin{array}{l}\text { Vállalkozói } \\
\text { környezet }\end{array}$ & $\begin{array}{l}\text { Nem megfelelő és alkalmatlan kormányzati vagy } \\
\text { politikai támogatás } \\
\text { Elégtelen helyi kereslet } \\
\text { Az elosztott megújuló energia ára } \\
\text { Nem megfelelő hozzáférés az intézményi forrásokhoz } \\
\text { Képzett munkaerő hiánya } \\
\text { A piacon jelen lévő szolgáltatók ereje } \\
\text { Fejletlen fizikai infrastruktúra }\end{array}$ & $\begin{array}{c}\text { Gabriel, } \\
\text { Kirkwood, } \\
\text { Walton, Rose } \\
(2016)\end{array}$ \\
\hline $\begin{array}{l}\text { Decentralizált } \\
\text { megújuló } \\
\text { energiarendszerek }\end{array}$ & $\begin{array}{l}\text { Technikai } \\
\text { Gazdasági } \\
\text { Intézményi } \\
\text { Szocio-kulturális } \\
\text { Környezeti }\end{array}$ & $\begin{array}{l}\text { Yaqoot et.al. } \\
\quad(2016)\end{array}$ \\
\hline
\end{tabular}

Mindebből következik, hogy az energiaátmenet egyik ígéretes segítői a helyi szinten szerveződő megújuló energiát hasznosító megoldások, így az azokat megvalósító önkormányzatok. Sajátos müködésük, bürokratikus rendszerük és gazdálkodási kötöttségeik ugyanakkor nehezíthetik is a folyamat sikerét, társadalmi elfogadottságát.

Magyarország Nemzeti Energia- és Klímatervében is megjelenik a decentralizált (elosztott) energiatermelés támogatásának és előmozdításának az igénye, amely ,újra értelmezi az energiafüggetlenséget a fogyasztók szintjén, és támogatja a saját célra történö megújuló alapú decentralizált energiatermelést, ami egyszerre biztositja a fogyasztói választás lehetöségét, hozzájárul a költséghatékony energiaellátás biztositásához, segíti a programban részt vevök rezsiköltségének mérséklését, csökkenti az import energiától való függést, elösegiti a klimacélok teljesitését, és új üzleti lehetöségeket is teremt a berendezéseket elöállitó gyártó és az azokat telepitö szolgáltató cégek számára." (NEKT 2018, pp. 33.)

Az energiaátmenet egyenes ági következménye a települések mind nagyobb energiafüggetlensége, amelyet az elmúlt évek létesítési szándékai is jól tükröznek. Kulcsár (2020) tanulmányában energia- 
földrajzi és energiapolitikai szempontok mentén gyüjtötte össze azokat a magyarországi településeket, amelyeken a háztartási méretü és $0,5 \mathrm{MW}$ alatti beépített teljesítőképességű erőmüvek a villamosenergia ellátás terén végrehajtották az energiaátmenet. A szerző energiaváltásnak nevezi, de lényegében a korábbiakban ismertetekkel megegyező fogalomról van szó. Hiánypótló vizsgálata alanyai Magyarország 3155 települése, így egy megbízható és átfogó képet ad 2017-re vonatkozóan. Az önellátó és a villamosenergia transzfer mellett önellátó települések számát regionális bontásban a 3. táblázat foglalja össze.

3. táblázat Az önellátó és a villamosenergia import mellett önálló települések száma régiónként

\begin{tabular}{|l|c|c|}
\hline Régió & $\mathbf{1 0 0 \%}$-ban önellátó település & $\begin{array}{c}\text { Import mellett önellátó } \\
\text { település }\end{array}$ \\
\hline Észak-Magyarország & 12 & 15 \\
\hline Észak-Alföld & 2 & 1 \\
\hline Dél-Alföld & 1 & 1 \\
\hline Dél-Dunántúl & 8 & 9 \\
\hline Közép-Dunántúl & 2 & 1 \\
\hline Közép-Magyarország & 2 & 0 \\
\hline Nyugat-Dunántúl & 3 & 2 \\
\hline Összesen & $\mathbf{3 0}$ & $\mathbf{2 9}$ \\
\hline
\end{tabular}

Forrás: (Kulcsár 2020, pp. 417.) alapján saját szerkesztés

Az energiatranszfer (export) a település villamosenergia igényének kielégítését követően keletkezett többlet energiát jelenti. A tanulmány becslő számítása szerint 3155 településből 30 már teljes mértékben, 29 pedig energiatranszfer segítségével önellátónak számít. (Kulcsár, 2020) Természetesen ez még jelenleg alacsony aránynak számít, de ha figyelembe vesszük a 2018-2020-as önkormányzati megújuló energiát hasznosító erőművi telepítéseket (4. táblázat), valamint az egyre fokozódó települési összefogásokat a fenntartható energia- és klíma érdekében, már egy kedvezőbb képet kapunk.

4. táblázat Megújuló energia telepitését tervezö, és létesitési engedéllyel rendelkezö települések

\begin{tabular}{|c|l|l|c|l|c|}
\hline Ssz. & \multicolumn{1}{|c|}{ Település } & \multicolumn{1}{c|}{ Régió } & Év & \multicolumn{1}{c|}{ Megújuló energia } & Beépített kapacitás \\
\hline 1. & Litér & Közép-Dunántúl & 2018 & fotovoltaikus (PV) & $99 \mathrm{MW}$ \\
\hline 2. & Felsőzsolca & Észak-Magyarország & 2018 & fotovoltaikus (PV) & $20 \mathrm{MW}$ \\
\hline 3. & Ócsa & Közép-Magyarország & 2019 & fotovoltaikus (PV) & $2 \times 54,4 \mathrm{MW}$ \\
\hline 4. & Almásfüzitő & Közép-Dunántúl & 2019 & $\begin{array}{l}\text { kombinált ciklusú } \\
\text { erőmú (CCGT) }\end{array}$ & $2 \times 400-430 \mathrm{MW}$ \\
\hline 5. & Kunmadaras & Észak-Alföld & 2021 & fotovoltaikus (PV) & $200 \mathrm{MW}$ \\
\hline 6. & Kalocsa & Dél-Alföld & 2021 & fotovoltaikus (PV) & $200 \mathrm{MW}$ \\
\hline 7. & Taszár & Dél-Dunántúl & 2021 & fotovoltaikus (PV) & $250 \mathrm{MW}$ \\
\hline 8. & Szeged & Dél-Alföld & 2021 & $\begin{array}{l}\text { kombinált ciklusú } \\
\text { erömü (CCGT) }\end{array}$ & $2 \times 460 \mathrm{MW}$ \\
\hline
\end{tabular}

Forrás: (MAVIR 2017, pp. 20-21.) alapján saját szerkesztés 
A MAVIR 2017-es beszámolója alapján összeállított 4. táblázat a megújuló villamosenergia keretében megvalósult és megvalósulni szándékozó települési megújuló kapacitásokat mutatja be. 2021-re várhatóan 2627,8 MW új beépített teljesítőképesség szolgálja majd a fogyasztókat. Az önellátó települések közül az Észak-magyarországi régió jár az élen, de 2019-et követően a Közép-dunántúli régió és a Dél-Alföld erösödése várható. Ezt a tendenciát igazolják a TOP-6.5.2-15 önkormányzatok által vezérelt helyi közcélú energiaellátás megvalósítása megújuló energiaforrások felhasználásával és a TOP-3.2.2-15 önkormányzatok által vezérelt, a helyi adottságokhoz illeszkedő, megújuló energiaforrások kiaknázására irányuló energiaellátás megvalósítása, komplex fejlesztési programok keretében nevet viselő pályázat segítségével megvalósuló beruházások is. (palyazat.gov.hu) Az önkormányzatok a kötelezően ellátandó feladataikon túlmenően egyre gyakrabban csatlakoznak olyan kezdeményezésekhez, és fejlesztésekhez is, amelyekkel nem csak megtakarításokat tudnak elérni, de az energiaátmenet élére állva megvalósíthatják a maguk és szükebb környezetük (lakosság és vállalkozások) mind nagyobb jólétét.

\section{4 Összegzés}

Az energiaátmenet, a közösségi energia és a társadalmi innováció kérdéskörét a tudományos világ mind szélesebb érdeklődése övezi. A lineáris gazdaság modellje által generált és elmélyített gazdasági és társadalmi problémák egyik megoldását a szakértők a társadalmi innovációkban és az energiaátmenetben látják. Az Európai Unió a lokális szereplőknek mind nagyobb szerepet szánva megalkotta az Új Megújuló- és Villamosenergia Irányelvét, amelyben megteremti a helyi lakosságnak és közösségeknek az energiapiacon való diszkrimináció mentes jelenlétet. A közösségi energiatermelés, mint a társadalmi innováció egy lehetséges formája jellemzően a megújuló energiák felhasználásán alapszik, így hathatós támogatója az energiaátmenetnek. Magyarországon jelenleg még jogilag nem rendezett a közösségi energia ügye. Ennek ellenére már számos település elérte villamosenergia ellátásának a fosszilis energiahordozóktól való függetlenítését. A kutatás folytatásának egy lehetséges irányát jelenti a 2021 január 1-jén hatályba lépő energiahatékonysági kötelezettségi rendszer hazai hatásainak a feltárása.

\section{Köszönetnyilvánítás}

A cikkben ismertetett kutató munka az EFOP-3.6.1-16-2016-00011 jelü „Fiatalodó és Megújuló Egyetem - Innovatív Tudásváros - a Miskolci Egyetem intelligens szakosodást szolgáló intézményi fejlesztése" projekt részeként - a Széchenyi 2020 keretében - az Európai Unió támogatásával, az Európai Szociális Alap társfinanszírozásával valósul meg.

\section{Irodalom}

[1] Alves, M., Segurado, R. \& Costa, M., (2019): On the road to 100\% renewable energy systems in isolated islands, in: Energy $198 \quad$ (2020) $117321, \quad$ pp. $1-9$. https://doi.org/10.1016/j.energy.2020.117321

[2] Cossent, R., Gómez, T. \& Frías, P. (2009.): Towards a future with large penetration of distributed generation: Is the current regulation of electricity distribution ready? Regulatory recommendations under a European perspective. Energy Policy. Volume:37 Number: 3 March 2009, pp. 1145-1155. https://doi.org/10.1016/j.enpol.2008.11.011 
[3] Gancheva, M., O’Brien, S., Crook, N.; Monteiro, C. (2018.): Models of Local Energy Ownership and the Role of Local Energy Communities in Energy Transition in Europe. Milieu LTd, Belgium, European Committee of the Regions.

[4] IRENA (2019a.): Innovation landscape brief: Future role of distribution system operators, Abu Dhabi: International Renewable Energy Agency.

[5] IRENA (2019b.): Global Energy Transformation: A Roadmap to 2050, Abu Dhabi

[6] Kádárné Horváth Ágnes, Takácsné Papp Adrienn (2019): A közösségi energia, mint az energiaszektor egy lehetséges társadalmi innovációs megoldása In: Köszegi, Irén Rita (szerk.) III. Gazdálkodás és Menedzsment Tudományos Konferencia : Versenyképesség és innováció Kecskemét, Magyarország : Neumann János Egyetem Kertészeti és Vidékfejlesztési Kar, (2019) pp. 768-774., 7 p.

[7] Kocziszky György; Veresné Somosi Mariann; Balaton Károly (2017): A társadalmi innováció vizsgálatának tapasztalatai és fejlesztési lehetőségei. Vezetéstudomány / Budapest Management Review XLVIII. évf. 2017. 6-7. szám / ISSN 0133-0179 https://doi.org/10.14267/VEZTUD.2017.06.02

[8] Kulcsár, B. (2020): A megújuló forrásból származó villamos energia önellátási és exportlehetöségei a magyarországi településeken. Területi Statisztika, 60(4). kötet, pp. 399-424. https://doi.org/10.15196/TS600401

[9] Lepesant, G. (2017): Implementing EU Renewable Energy Policy at the Subnational Level: Navigating between Conflicting Interests. WIDER Working Paper 2016/29. Helsinki: UNUWIDER. https://doi.org/10.35188/UNU-WIDER/2016/072-0

[10] Selvakkumaran, S.; Ahlgren, E. O. (2021): Understanding social innovation in local energy transitions processes: A multi-case study. Global Transitions, 3. kötet, pp. 1-12. https://doi.org/10.1016/j.glt.2020.12.001

[11] Slee, B. (2020): Social innovation in community energy in Scotland: Institutional form and sustainability outcomes. Global Transitions, 2. kötet, pp. 157-166. https://doi.org/10.1016/j.glt.2020.07.001

[12] Smil, V. (2016): Examining energy transitions: A dozen insights based on performance in: Energy Research \& Social Science 22, pp. 194-197. https://doi.org/10.1016/j.erss.2016.08.017

[13] Sovacool, B. K. (2016): How long will it take? Conceptualizing the temporal dynamics of energy transitions in: Energy Research \& Social Science 13, p. 202-215. https://doi.org/10.1016/j.erss.2015.12.020

[14] Sveinbjörnsson, D. és mtsai. (2017) Energy supply modelling of a low-CO2 emitting energy system: Case study of a Danish municipality. Applied Energy 195, p. 922-941. https://doi.org/10.1016/j.apenergy.2017.03.086

[15] Székffy, K. (2014): Az európai villamos-energia piac átalakulása a megújuló energiaforrások térnyerésének hatására. Közgazdasági Szemle, LXI. évf. 2014. június, pp. 719-745.

[16] Vezzoli, C. és mtsai. (2018): Designing Sustainable Energy for All Sustainable Product-Service System Design Applied to Distributed Renewable Energy, Springer. https://doi.org/10.1007/978-3-319-70223-0_3

[17] Bertram, R.- Primova, R. (szerk.) (2018): Energy Atlas 2018. Facts and figures about renewables in Europe. https://www.boell.de/sites/default/files/energyatlas2018_facts-and-figuresrenewables-europe.pdf.pdf?dimensionl=ds_energyatlas_(letöltve 2018.09.)

[18] Európai Bizottság, (2019): Vitaanyag-Fenntartható Európa 2030-ra https://ec.europa.eu/commission/sites/beta-

political/files/rp_sustainable_europe_hu_v2_web.pdf (letöltve: 2020.03.25.) 
[19] Eurostat (2019): Sustainable development in the European Union Monitoring report on progress towards the SDGs in an EU context, doi:10.2785/44964 https://ec.europa.eu/eurostat/documents/3217494/9940483/KS-02-19-165-EN-N.pdf/1965d8f54532-49f9-98ca-5334b0652820 (letöltve: 2020.02.)

[20] Fellegi Dénes, Fülöp Orsolya (2012): Szegénység vagy energiaszegénység? Az energiaszegénység definiálása Európában és Magyarországon, ENERGIAKLUB https://energiaklub.hu/files/study/energiaklub_szegenyseg_vagy_energiaszegenyseg.pdf (letöltve: 2020.05.)

[21] KSH (2019): A fenntartható fejlődés indikátorai Magyarországon, 2018 ISSN: 2064-0307 http://www.ksh.hu/docs/hun/xftp/idoszaki/fenntartfejl/fenntartfejl18.pdf (letöltve: 2020.04.)

[22] MAVIR (2017): Éves Beszámoló 2017 https://www.mavir.hu/documents/10258/107819/MAVIR_EvesJelentes2017_HU.pdf/33b07f4a$c 20 d-b c 3 c-d l f 0-7498 b e 506387 ? t=1555071912061$ (letöltve: 2020.05 .)

[23] Magyar László (2016): Közösségi Energia. Energia a közösség szolgálatában. Energiaklub, 2016. augusztus 13. https://energiaklub.hu/node/4062 (letöltve 2018.08.10.)

[24] NEKT (2018): Magyarország Nemzeti Energia- és Klíma Akcióterve. https://ec.europa.eu/energy/sites/ener/files/documents/hu_final_necp_main_hu.pdf (letöltve: 2020.04.)

[25] OECD, IEA, IRENA (2017): Perspectives for the Energy Transitions - Investment Needs for a Low-Carbon Energy System https://www.irena.org/publications/2017/Mar/Perspectives-for-theenergy-transition-Investment-needs-for-a-low-carbon-energy-system (letöltve: 2020. 05.)

[26] Tounquet, F. (2019): Energy Communities in the European Union https://asset-ec.eu/wpcontent/uploads/2019/07/ASSET-Energy-Comminities-Revised-final-report.pdf letöltve: 2020.04.)

[27] World Economic Forum-WEF (2019a.): Energy Transition Index http://reports.weforum.org/fostering-effective-energy-transition-2019/energy-transitionindex/energy-transition-index-ranking/

[28] World Economic Forum-WEF (2019b.): Fostering Effective Energy Transition 2019. edition, World Economic Forum;

http://www3.weforum.org/docs/WEF_Fostering_Effective_Energy_Transition_2019.pdf (letöltve 2021.01.)

[29] Lisszaboni szerződés (EU 2007/C 360/0)

[30] Az Európai Unió működésről szóló szerződés, 2012.

[31] EPOV (Energy Poverty Observatory): https://www.energypoverty.eu/about/what-energy-poverty

[32] EU 2018/2001 Az Európai Parlament és a Tanács (EU) 2018/2001 irányelve (2018. december 11.) A megújuló energiaforrásokból elöállitott energia használatának elömozditásáról (átdolgozás) (EGT-vonatkozású szöveg)

[33] EU 2019/944, Az Európai Parlament és a Tanács (EU) 2019/944 Irányelve a villamos energia belsö piacára vonatkozó közös szabályokról és a 2012/27/EU irányelv módositásáról (átdolgozás)

[34] Eurostat a.: Energia import függöség [nrg_ind_id] https://appsso.eurostat.ec.europa.eu/nui/show.do?dataset=nrg_ind_id\&lang=en (letöltve: 2020.05.25.) 
[35] Eurostat b., Az európai unió energiafogyasztása [nrg_bal_c] https://appsso.eurostat.ec.europa.eu/nui/show.do?dataset=nrg_bal_c\&lang=en (letöltve: 2020.05.25.)

[36] Eurostat c.: Háztartások egy före esö végső energia fogyasztása [sdg_07_20] http://appsso.eurostat.ec.europa.eu/nui/show.do?dataset $=s d g \_07 \_20 \& l a n g=e n$ (letöltve: 2020.05.)

[37] Eurostat d., Energia produktivitás [nrg_ind_ep] https://data.europa.eu/euodp/en/data/dataset/HKoQCaFeIcOaCYnmhtUb8A (letöltve: 2020.05.)

[38] Eurostat e.: Energia fogyasztás ÜHG intenzitása [sdg_13_20 ] http://appsso.eurostat.ec.europa.eu/nui/show.do?dataset=sdg_07_60\&lang=en (letöltve: 2020.05..)

[39] Eurostat f.: Lakosság aránya, akik nem tudják megfelelöen füteni az otthonukat [sdg_07_60] http://appsso.eurostat.ec.europa.eu/nui/show.do?dataset=sdg_07_60\&lang=en (letöltve: 2020.05.)

[40] Eurostat g.: Megújuló energia aránya a bruttó végső energiafelhasználásban [2020_rd330] https://ec.europa.eu/eurostat/web/products-datasets/-/t2020_rd330 (letöltve: 2020.05.)

[41] Eurostat h.: Üvegházhatású gázkibocsátás, 1990=100\% [t2020_30] https://ec.europa.eu/eurostat/tgm/table.do?tab=table\&init $=1$ \&language $=e n \& p c o d e=t 2020 \_30$ \&plugin=1 (letöltve: 2020.05.)

[42] Pályázati portál: https://www.palyazat.gov.hu/tamogatott_projektkereso

Elektronikus források utolsó ellenőrzése 2021.01.04. 